\title{
Ubiquitin-specific Peptidase 6 (USP6)-associated Fibroblastic/Myofibroblastic Tumors: Evolving Concepts
}

\author{
SHIZUHIDE NAKAYAMA ${ }^{1 *}$, JUN NISHIO ${ }^{1 *}$, MIKIKO AOKI ${ }^{2}$, KAORI KOGA $^{2}$, \\ KAZUKI NABESHIMA ${ }^{2}$ and TAKUAKI YAMAMOTO ${ }^{1}$ \\ ${ }^{1}$ Department of Orthopaedic Surgery, Faculty of Medicine, Fukuoka University, Fukuoka, Japan; \\ ${ }^{2}$ Department of Pathology, Faculty of Medicine, Fukuoka University, Fukuoka, Japan
}

\begin{abstract}
Ubiquitin-specific peptidase 6 (USP6) is a hominoid-specific gene residing on chromosome $17 p 13$ and serves as a deubiquitinating enzyme with a diverse set of functions including intracellular trafficking, inflammatory signaling, cell transformation and protein turnover. USP6 rearrangements were first identified in aneurysmal bone cysts, resulting in promoter swapping and over-expression of wild type USP6. Several morphologically overlapping fibroblasticl myofibroblastic tumors are known to harbor USP6 rearrangements, including nodular fasciitis, cellular fibroma of tendon sheath, myositis ossificans and fibro-osseous pseudotumor of digits. Over the past few years, fusions involving the USP6 gene and various partner genes have been described in these neoplasms. The current World Health Organization Classification of Tumors of Soft Tissue suggests that USP6-rearranged lesions are typically benign and usually self-limited in their growth. This review provides an updated overview of the clinical, histological and molecular genetic features of USP6-associated fibroblastic/myofibroblastic tumors and discusses how these lesions should be best classified.
\end{abstract}

Ubiquitin-specific peptidase 6 (USP6), located on chromosome $17 \mathrm{p} 13$, is a hominoid-specific gene primarily expressed in testicular tissue and encodes a deubiquitinating

This article is freely accessible online.

*These Authors contributed equally to this study.

Correspondence to: Jun Nishio, MD, Ph.D., Department of Orthopaedic Surgery, Faculty of Medicine, Fukuoka University, 745-1 Nanakuma, Jonan-ku, Fukuoka 814-0180, Japan. Tel: +81 928011011, Fax: +81 928649055, e-mail: jnishio@cis.fukuokau.ac.jp

Key Words: Nodular fasciitis, fibroma of tendon sheath, myositis ossificans, fibro-osseous pseudotumor of digits, USP6, review. enzyme that plays critical roles in diverse cellular processes such as intracellular trafficking, inflammatory signaling, cell transformation and protein turnover $(1,2)$. USP6 was initially cloned from transfected DNA of human Ewing sarcoma cells (3). USP6 rearrangements were first identified in a primary aneurysmal bone cyst (ABC) (4). Subsequently, various fusion partners for USP6 were discovered in $\mathrm{ABC}$ (5). These alternative gene fusions induce tumorigenesis by a promoter-swapping mechanism that drives transcriptional up-regulation of USP6. It was also shown that USP6 induces expression of matrix metalloproteinase through activation of the classical nuclear factor-kappaB pathway (6). Furthermore, recent studies demonstrated that USP6 promotes tumorigenesis through multiple pathways, including Wnt, Jak1-STAT3 and c-Jun (7-9).

The new fifth edition of the World Health Organization Classification of Tumors of Soft Tissue was published in early 2020. Several benign fibroblastic/myofibroblastic tumor subtypes are characterized by certain morphologies or distinctive anatomical distributions, including nodular fasciitis, cellular fibroma of tendon sheath, myositis ossificans and fibro-osseous pseudotumor of digits. Most notably, these benign tumors usually harbor USP6 rearrangements (10-13). In this review, we present an updated overview of the clinical, histological and molecular genetic features of USP6-associated fibroblastic/myofibroblastic tumors and discusses their relationships to one another. The corresponding clinicopathological and molecular characteristics are summarized in Table I.

\section{Nodular Fasciitis}

Nodular fasciitis is a benign self-limited fibroblastic/ myofibroblastic neoplasm of unknown etiology. It equally affects males and females and occurs in all age groups but more often in young adults (20 to 40 years of age). The upper extremities are most frequently affected, followed by trunk and 
Table I. Clinicopathological and molecular characteristics of USP6-associated fibroblastic/myofibroblastic tumors.

\begin{tabular}{|c|c|c|c|}
\hline Entity & Clinical features & Histological features & USP6 fusion partners \\
\hline Nodular fasciitis & $\begin{array}{l}\text { Third to fourth decades; } \\
\text { Equal male and female incidence. } \\
\text { Most cases involve the } \\
\text { subcutaneous tissue } \\
\text { and underlying fascia. }\end{array}$ & $\begin{array}{l}\text { Circumscribed or infiltrative lesion, } \\
\text { composed of plump (myo)fibroblasts } \\
\text { in a myxoid or collagenous stroma } \\
\text { with a tissue culture-like growth pattern; } \\
\text { Extravasated erythrocytes, lymphocytes } \\
\text { and osteoclast-like giant cells are common. }\end{array}$ & $\begin{array}{c}\text { MYH9, RRBP1, CALU, } \\
\text { CTNNB1,MIR22HG, } \\
\text { SPARC, THBS2, COL6A2, } \\
\text { SEC31A, EIF5A, COL1A1, } \\
\text { COL1A2, PAFAH1B1, SERPINH1, } \\
\text { COL3A1 and PPP6R3 }\end{array}$ \\
\hline $\begin{array}{l}\text { Cellular fibroma } \\
\text { of tendon sheath }\end{array}$ & $\begin{array}{l}\text { Third to fifth decades; } \\
\text { Male predominance. } \\
\text { Most cases attach to } \\
\text { the tendon (sheath). }\end{array}$ & $\begin{array}{c}\text { Increased cellularity compared } \\
\text { with classical fibroma of tendon sheath; } \\
\text { Well-circumscribed lesion, composed } \\
\text { of spindled (myo)fibroblasts in a } \\
\text { collagenous stroma. Slit-like vessels are } \\
\text { present at the periphery. }\end{array}$ & $\begin{array}{c}M Y H 9, C O L 1 A 1, C O L 3 A 1, \\
P K M, R C C 1 \text { and } A S P N\end{array}$ \\
\hline Myositis ossificans & $\begin{array}{l}\text { Second to third decades; } \\
\text { Equal male and female incidence. } \\
\text { Most cases occur in the } \\
\text { skeletal muscle. }\end{array}$ & $\begin{array}{l}\text { Well-delineated lesion; } \\
\text { Zoning phenomenon with immature } \\
\text { bone at the center and mature } \\
\text { bone at the periphery. } \\
\text { Early ( }<6 \text { weeks) lesion demonstrates } \\
\text { a close resemblance to nodular fasciitis. }\end{array}$ & COL1A1 \\
\hline $\begin{array}{l}\text { Fibro-osseous } \\
\text { pseudotumor of digits }\end{array}$ & $\begin{array}{l}\text { Second to fourth decades; } \\
\text { Female predominance. } \\
\text { Most cases occur in the } \\
\text { subcutaneous tissue. }\end{array}$ & $\begin{array}{l}\text { Less well-delineated lesion compared } \\
\text { with myositis ossificans; } \\
\text { Most cases have myositis } \\
\text { ossificans-like histological features, } \\
\text { composed of (myo)fibroblastic/ } \\
\text { osteoblastic cells in a collagenous to } \\
\text { myxoid stroma. Zoning phenomenon } \\
\text { may or may not be evident. }\end{array}$ & COL1A1 \\
\hline
\end{tabular}

USP6: Ubiquitin-specific peptidase 6; MYH9: myosin heavy chain 9; RRBP1: ribosome binding protein 1; CALU: calumenin; CTNNB1: catenin beta 1; MIR22HG: MIR22 host gene; SPARC: secreted protein acidic and cysteine rich; THBS2: thrombospondin 2; COL6A2: collagen type VI alpha 2 chain; SEC31A: SEC31 homolog A; COPII: coat complex component; EIF5A: eukaryotic translation initiation factor 5A; COL1A1: collagen type I alpha 1 chain; COL1A2: collagen type I alpha 2 chain; PAFAH1B1: platelet activating factor acetylhydrolase 1b regulatory subunit 1; SERPINH1: serpin family $\mathrm{H}$ member 1; COL3A1: collagen type III alpha 1 chain; PPP6R3: protein phosphatase 6 regulatory subunit 3; PKM: pyruvate kinase $\mathrm{M} 1 / 2 ; R C C 1$ : regulator of chromosome condensation 1; $A S P N$ : asporin.

head and neck. Most cases involve the subcutaneous tissue and underlying fascia. Nodular fasciitis typically grows rapidly and reaches its final size within a few weeks. Mild pain or tenderness may be present. The lesion usually measures 2 to 3 $\mathrm{cm}$ in diameter. Several subtypes of nodular fasciitis are recognized on the basis of the anatomical location, including intravascular fasciitis and cranial fasciitis (14).

Histologically, nodular fasciitis consists of a proliferation of spindle-shaped cells in a myxoid or collagenous stroma. The neoplastic cells are typically slender and delicate, mimicking the appearance of fibroblasts in tissue culture and are arranged in whorls, short fascicles or haphazardly (Figure 1A). Mitotic activity is easily identified but atypical mitoses are not observed. Extravasated erythrocytes, lymphocytes and osteoclast-like giant cells are frequently identified (14). Occasionally, osseous metaplasia may be present as seen in myositis ossificans and fibro-osseous pseudotumor of digits
(13). Immunohistochemically, the neoplastic cells are usually positive for smooth muscle actin (SMA) (Figure 1B) and muscle specific actin (MSA). Focal desmin expression is occasionally found.

Clonal chromosomal aberrations were detected in five cases of nodular fasciitis (15-19). Rearrangements involving $3 q 21$ and 15q22-q26 were identified in a small subset of nodular fasciitis.

In 2011, USP6 rearrangements were detected in 44 of 48 $(92 \%)$ cases of nodular fasciitis (20). In that study, myosin heavy chain 9 (MYH9), located on chromosome 22q12.3, was identified as a novel fusion partner and it was shown that increased expression of USP6 could induce formation of a tumor clinically and histologically similar to human nodular fasciitis in xenograft models. Since then, various USP6 fusion partners were discovered in nodular fasciitis and its subtypes, including ribosome binding protein 1 ( $R R B P 1)$, calumenin 
$(C A L U)$, catenin beta 1 (CTNNB1), MIR22 host gene $(M I R 22 H G)$, secreted protein acidic and cysteine rich (SPARC), thrombospondin 2 (THBS2), collagen type VI alpha 2 chain (COL6A2), SEC31 homolog A, COPII coat complex component $(S E C 31 A)$, eukaryotic translation initiation factor 5A (EIF5A), collagen type I alpha 1 chain (COL1A1), collagen type I alpha 2 chain (COL1A2), platelet activating factor acetylhydrolase $1 \mathrm{~b}$ regulatory subunit 1 (PAFAH1B1), serpin family $\mathrm{H}$ member 1 (SERPINHI) and collagen type III alpha 1 chain (COL3A1) (21-27). Some fusion partners appear to be shared across neoplasms $(5,24)$. These molecular studies indicate that the most frequent fusion partner of USP6 is MYH9 in nodular fasciitis. Wang et al. (24) suggested that the MYH9-USP6 fusion is not related bone formation. Furthermore, a protein phosphatase 6 regulatory subunit 3 (PPP6R3)-USP6 fusion with gene amplification was detected in two cases of nodular fasciitis with malignant behavior (28, 29). It is suggested that this fusion and/or USP6 amplification may be associated with malignant condition. However, further studies with a large number of cases are needed to better understand the correlation between certain gene fusions and distinct biological behavior.

\section{Cellular Fibroma of Tendon Sheath}

Fibroma of tendon sheath is a benign fibroblastic/ myofibroblastic neoplasm that is usually attached to a tendon (sheath) of the fingers. It may occur at any age but has a peak incidence in the third to fifth decades of life, with a male predominance. Fibroma of tendon sheath typically presents as a firm, small (usually less than $3 \mathrm{~cm}$ ), slowgrowing, painless mass (30). A cellular variant of this neoplasm has been described as having morphological overlap with nodular fasciitis (31).

Histologically, fibroma of tendon sheath consists of bland spindle cells in a dense collagenous stroma (Figure 2A). Cytological atypia is not observed and mitotic activity is low. There are characteristic slit-like thin-walled vessels or clefts at the periphery of the lesion. Degenerative features such as myxoid change, osseous metaplasia and pleomorphism may be present (30). Cellular fibroma of tendon sheath is generally defined as a tumor having areas of increased cellularity and a nodular fasciitis-like appearance as well as identifiable histological features of classical fibroma of tendon sheath (Figure 2B). Immunohistochemically, the neoplastic cells are often positive for SMA (Figure 2C). Expression of desmin, S100 protein and FOS-like antigen 1 is absent (32).

Clonal chromosomal alterations were detected in four cases of classical fibroma of tendon sheath (33-36). These cytogenetic studies suggest that $11 \mathrm{q}$ rearrangement may be characteristic of classical fibroma of tendon sheath. It is of interest that this chromosomal rearrangement has also been observed in desmoplastic fibroblastoma (32), which can show

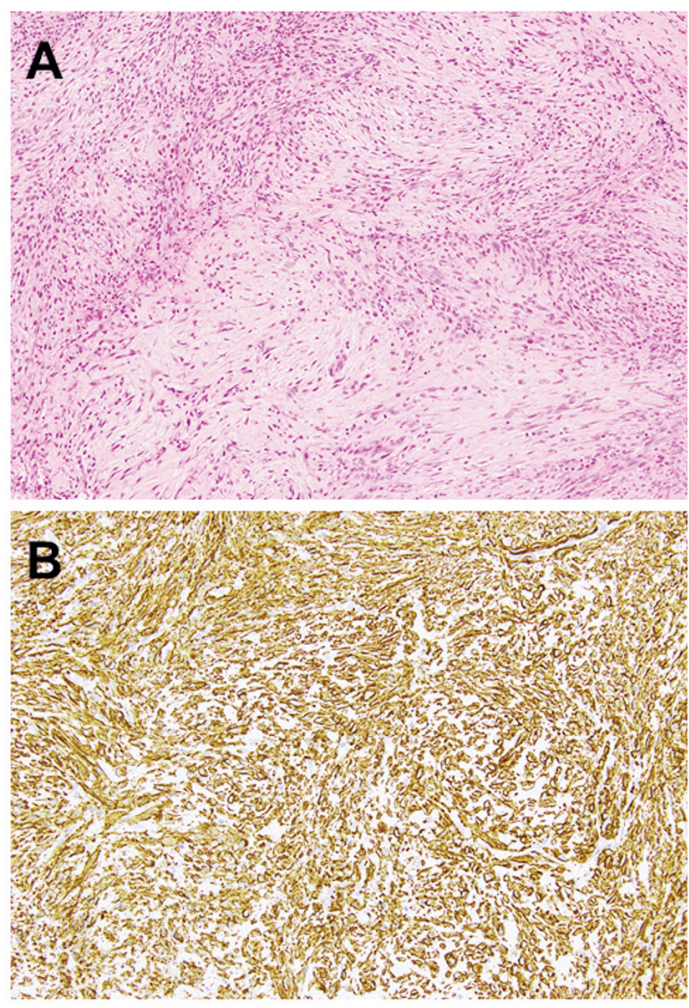

Figure 1. Histological and immunohistochemical features of nodular fasciitis. A: Nodular fasciitis consists of plump spindle-shaped cells with a vague fascicular and storiform pattern. Extravasated erythrocytes and lymphocytes can be observed (hematoxylin and eosin staining, original magnification $\times 100)$. B: The neoplastic cells are diffusely positive for smooth muscle actin (original magnification $\times 200)$.

morphological overlap with classical fibroma of tendon sheath.

Cellular fibroma of tendon sheath appears to be genetically distinct from classical fibroma of tendon sheath. UPS6 rearrangements were detected in 6 of $9(67 \%)$ cases of cellular fibroma of tendon sheath but not in classical fibroma of tendon sheath (37). In 2020, various USP6 fusion partners were discovered in a subset of cellular fibroma of tendon sheath, including pyruvate kinase M1/2 (PKM), regulator of chromosome condensation $1(R C C 1)$, asporin $(A S P N), C O L 1 A 1, C O L 3 A 1$ and MYH9 $(24,38)$. In view of the similar morphological and molecular genetic features, a subset of cellular fibroma of tendon sheath may in fact be tenosynovial nodular fasciitis.

\section{Myositis Ossificans and Fibro-Osseous Pseudotumor of Digits: Are they Related?}

According to the current World Health Organization Classification of Tumors of Soft Tissue, myositis ossificans and fibro-osseous pseudotumor of digits belong to the same neoplastic spectrum, with definite bone-forming capacity (39). 

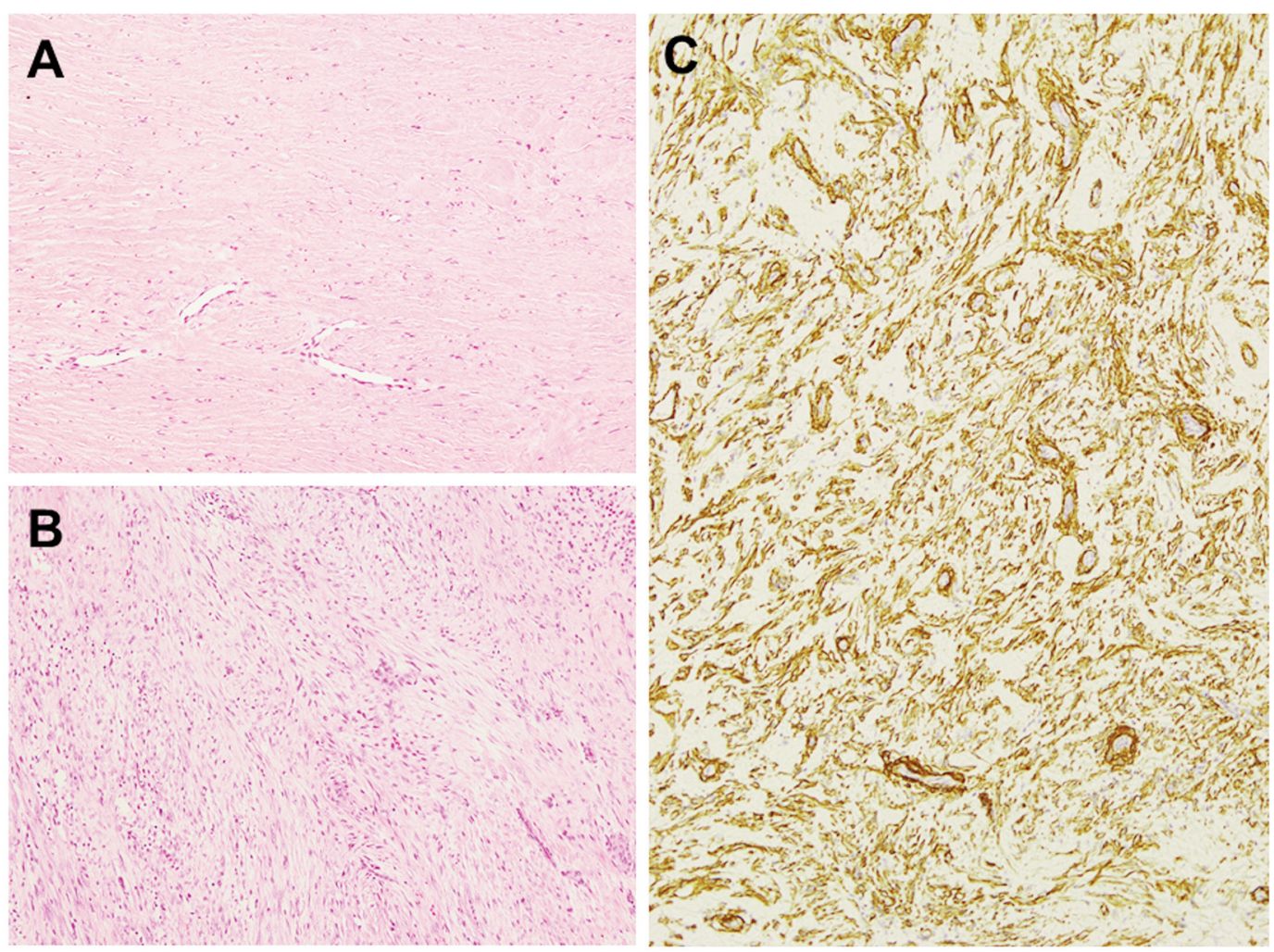

Figure 2. Histological and immunohistochemical features of classical and cellular variants of fibroma of tendon sheath. A: Classical fibroma of tendon sheath consists of bland spindle cells in a dense collagenous stroma. Slit-like vessels can be seen (hematoxylin and eosin staining, original magnification $\times 100$ ). B: Cellular fibroma of tendon sheath contains areas of increased cellularity composed of spindled-to-stellae cells arranged in a vague fascicular pattern (hematoxylin and eosin staining, original magnification $\times 100$ ). C: The tumor cells are positive for smooth muscle actin (original magnification $\times 100$ ).

Myositis ossificans is a benign self-limited fibroblastic/ myofibroblastic neoplasm typically occurring within the skeletal muscle. A history of trauma is sometimes absent, and the lesion may be an incidental finding. It equally affects males and females and usually occurs in physically active adolescents and young adults. Although myositis ossificans can occur anywhere in the body, the most common locations are the thigh, lower leg and buttock. Deep-seated lesions may involve both muscle and underlying periosteum. The clinical features depend on the phase; in the early phase (1-2 weeks), the involved area is swollen and painful. Eventually, it evolves into a firm, rapidly growing, painless mass (Figure 3A). The diameter ranges from 2 to $12.5 \mathrm{~cm}$ (median of $5 \mathrm{~cm}$ ) (40).

Histologically, myositis ossificans is characterized by the presence of a distinct zonal pattern with a peripheral rim of mature bone and a central cellular area composed of (myo)fibroblasts and immature bone (Figure 3B and C). In the early phase, myositis ossificans demonstrates a close resemblance to nodular fasciitis, with a highly cellular proliferation of (myo)fibroblasts within a variably myxoid stroma. The constituent (myo)fibroblasts display a mild degree of cellular pleomorphism and rather prominent mitotic activity. In the late phase, on the other hand, myositis ossificans consists almost entirely of mature lamellar bone. Woven bone rimmed by uniform osteoblasts is present throughout the lesion. Entrapment of atrophic muscle fibers is often observed. Necrosis is usually absent. Immunohistochemically, the neoplastic cells may express SMA and MSA, suggesting myofibroblastic differentiation.

In 2008, UPS6 rearrangements were identified in 2 cases with radiological and histological features consistent with myositis ossificans (41). These cases were at that time considered to be the early phase of soft-tissue $\mathrm{ABC}$ rather than myositis ossificans. In 2018, Bekers et al. (42) confirmed the presence of USP6 rearrangements in 8 of $9(89 \%)$ cases of myositis ossificans. Recently, COLIAl was detected as a fusion partner of USP6 in a subset of myositis ossificans $(24,43,44)$. It is of interest that this gene fusion has also been found in softtissue $\mathrm{ABC}(24,45,46)$. These findings suggest that myositis ossificans and soft-tissue $\mathrm{ABC}$ are closely related entities.

Fibro-osseous pseudotumor of digits is a rare benign selflimited neoplasm usually occurring in the subcutaneous tissue 

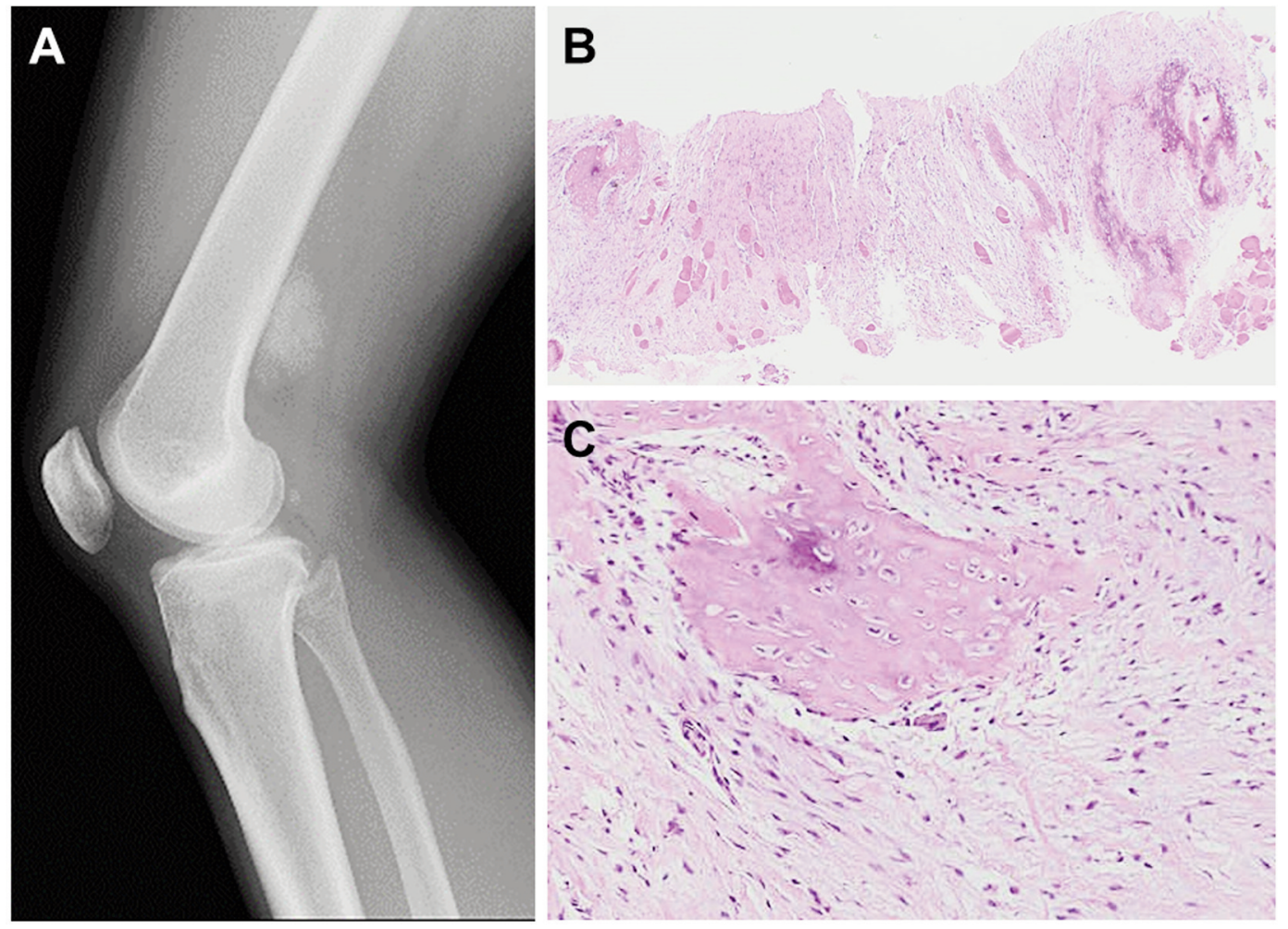

Figure 3. Radiographical and histological features of myositis ossificans. A: Lateral radiograph shows a densely mineralized mass in the posterior aspect of the distal thigh. B: Myositis ossificans shows a distinct zonal pattern with a central spindle cell proliferation surrounded by a peripheral bone formation. Skeletal muscle is entrapped (hematoxylin and eosin staining, original magnification $\times 20$ ). C: Myositis ossificans is composed of (myo)fibroblasts and foci of osteoid formation (hematoxylin and eosin staining, original magnification $\times 100$ ).

of the digits (Figure 4A). The etiology of this neoplasm remains unclear. It predominantly affects young to middle-aged adults, with a female predominance. The index finger appears to be a preferential location. Fibro-osseous pseudotumor of digits typically grows rapidly and the clinical features evolve over time. In the early phase, there is a variably painful fusiform swelling (47). Eventually, it becomes firm and well-demarcated. The diameter ranges from 0.2 to $5 \mathrm{~cm}$ (median of $1.5 \mathrm{~cm}$ ) (48).

The histological features of fibro-osseous pseudotumor of digits are very similar to those of myositis ossificans. Minor histological differences are believed to be related to the different location of involvement (40). Fibro-osseous pseudotumor of digits shows an irregular multinodular growth pattern and is histologically composed of a mixture of (myo)fibroblasts, osteoblasts and bony trabeculae with various stages of maturation (Figure $4 \mathrm{~B}$ and C). Like myositis ossificans, the zonal pattern may be seen (48). Mitotic activity may be high but abnormal mitotic figures are not observed. Immunohistochemically, the neoplastic cells may express SMA. No immunoreactivity has been reported for desmin, S-100 protein and CD34 (49).
In 2018, UPS6 rearrangements were detected in 4 of 5 $(80 \%)$ cases of fibro-osseous pseudotumor of digits (50). Recently, COL1Al was detected as a fusion partner of USP6 in a significant number of fibro-osseous pseudotumor of digits $(24,44)$. Intriguingly, almost all of bone-forming USP6-rearranged neoplasms adopt COL1Al as the fusion partner, including myositis ossificans, fibro-osseous pseudotumor of digits and soft-tissue $\mathrm{ABC}$. We suggest that these bone-forming soft tissue lesions belong to the same spectrum of USP6-induced neoplasms in light of their overlapping, occasionally indistinguishable morphology.

\section{Molecular Diagnostics}

In current practice, molecular genetic assays can serve as a useful diagnostic adjunct for soft tissue tumors (10). Notably, the development of next-generation sequencing has advanced our knowledge of molecular genetics in soft tissue tumors $(22,51)$.

Because of its rapid growth, high cellularity and high mitotic activity, nodular fasciitis can be misdiagnosed as a malignant soft tissue tumor such as low-grade fibrosarcoma 


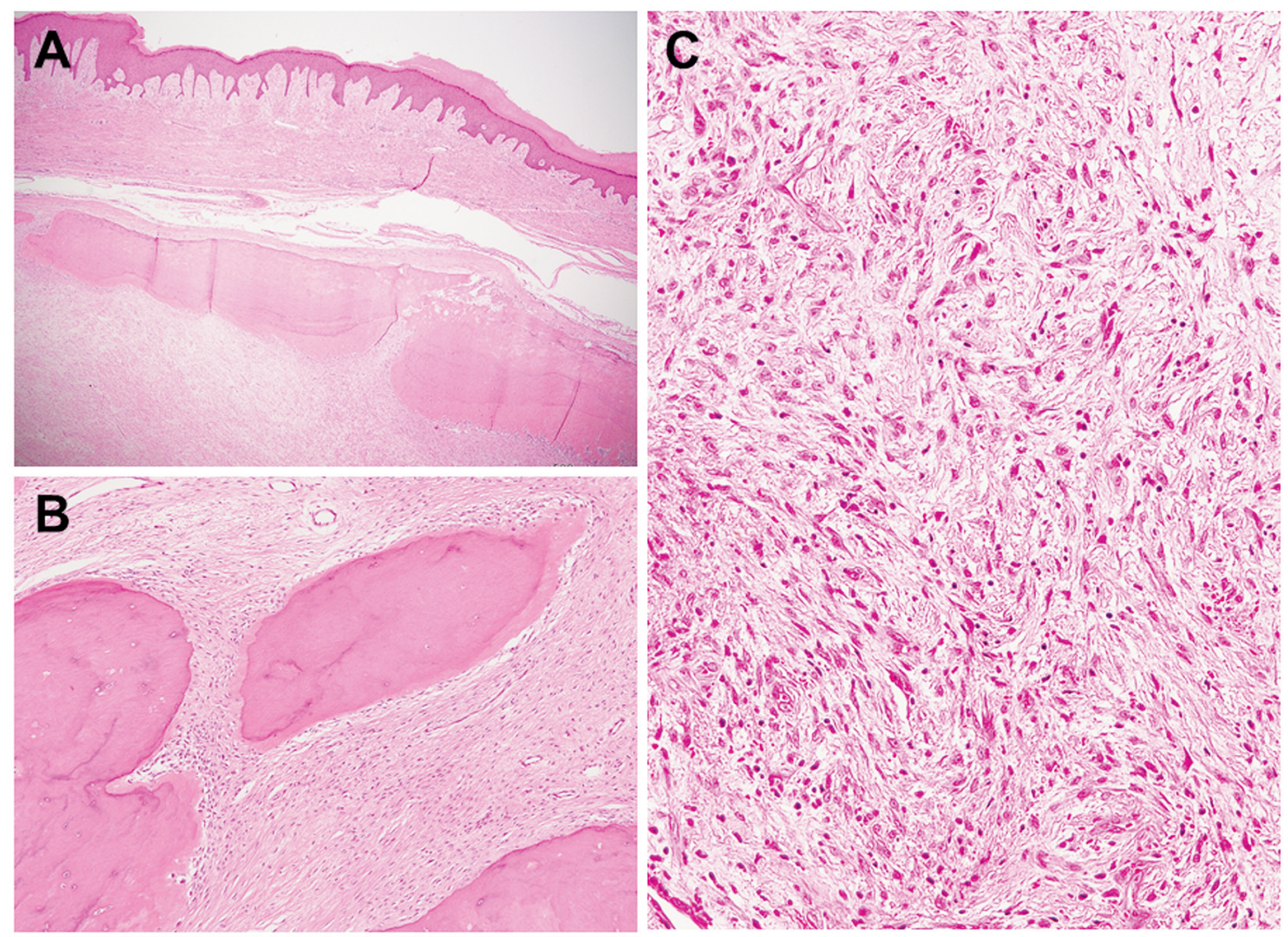

Figure 4. Histological features of fibro-osseous pseudotumor of digits. A: Fibro-osseous pseudotumor of digits involves the subcutaneous tissue. Mature bone is present at the periphery of the lesion (hematoxylin and eosin staining, original magnification $\times 20$ ). B: Fibro-osseous pseudotumor of digits shows a (myo)fibroblastic proliferation and mature woven bone formation (hematoxylin and eosin staining, original magnification $\times 100$ ). C: The central portion is composed of (myo)fibroblasts with a storiform pattern, resembling nodular fasciitis (hematoxylin and eosin staining, original magnification $\times 200$ ).

or low-grade myxofibrosarcoma, often leading to unnecessarily aggressive treatment. Similarly, myositis ossificans and fibro-osseous pseudotumor of digits can be easily confused with extraskeletal or parosteal osteosarcoma. Cellular fibroma of tendon sheath may be histologically confused with low-grade fibromyxoid sarcoma and lowgrade myofibroblastic sarcoma. It is of interest that the most important differential diagnoses do not show USP6 rearrangements. Therefore, the detection of USP6 rearrangements and/or USP6 fusions would be useful for the diagnosis of these benign fibroblastic/myofibroblastic neoplasms, especially in small biopsy specimens.

\section{Behavior and Treatment}

In our experience, conservative treatment is a reasonable firstline approach for benign self-limited neoplasms such as nodular fasciitis and myositis ossificans. In bone-forming cases, repeated radiographical examinations should be obtained during the follow-up period to document the maturation of the lesion and the absence of destructive growth.
Nodular fasciitis is a benign self-limiting process. Spontaneous regression is well documented and simple excision without attention to margins is sufficient. Local recurrence is very uncommon and typically cured by simple re-excision. Although extremely rare, malignant clinical behavior has been described in the literature $(28,29)$.

Simple excision is the treatment of choice for fibroma of tendon sheath but local recurrence is seen in $5-10 \%$ of cases (30). Recurrence is not aggressive and typically respond to simple re-excision. No cases of malignant transformation have been reported. There is no relationship between morphological variants and different clinical outcomes.

Undoubtedly, myositis ossificans and fibro-osseous pseudotumor of digits are benign self-limiting conditions similar to nodular fasciitis. Simple excision is the treatment of choice for these lesions and prognosis is excellent. Malignant transformation in myositis ossificans, usually into osteosarcoma, has been described (52) but it is exceptionally rare. On the other hand, there is no evidence of malignant transformation of fibro-osseous pseudotumor of digits. 


\section{Conclusion}

Almost all of USP6-associated fibroblastic/myofibroblastic tumors have a benign clinical course. Over the past decade, a number of novel fusions involving the USP6 gene have been identified in nodular fasciitis, cellular fibroma of tendon sheath, myositis ossificans and fibro-osseous pseudotumor of digits. These fusion partners act as an ectopic promotor leading to transcriptional activation of USP6. A subset of cellular fibroma of tendon sheath are probably in fact tenosynovial variants of nodular fasciitis. Myositis ossificans and fibro-osseous pseudotumor of digits may represent a morphological spectrum of the same biological entity, related to and sometimes indistinguishable from soft-tissue ABC. Further studies are required to determine whether different fusion partners are associated with distinct morphological features and biological behavior of USP6-induced neoplasms.

\section{Conflicts of Interest}

The Authors declare no conflicts of interest associated with this article.

\section{Authors' Contributions}

SN researched the literature and drafted the article. JN collected the data and was a major contributor to writing the article. MA, KK and $\mathrm{KN}$ performed the histological evaluations. TY reviewed the article. All Authors read and approved the final article.

\section{Acknowledgements}

The Authors are grateful to Dr. Hiroshi Iwasaki (Emeritus Professor, Department of Pathology, Faculty of Medicine, Fukuoka University) for his expert opinion and valuable comments on the histological diagnosis.

\section{References}

1 Paulding CA, Ruvolo $\mathrm{M}$ and Haber DA: The Tre2 (USP6) oncogene is a hominoid-specific gene. Proc Natl Acad Sci USA 100: 2507-2511, 2003. PMID: 12604796. DOI: 10.1073/ pnas.0437015100

2 Oliveira AM and Chou MM: The TRE17/USP6 oncogene: a riddle wrapped in a mystery inside an enigma. Front Biosci (Schol Ed) 4: 321-334, 2012. PMID: 22202063. DOI: 10.2741/271

3 Nakamura T, Hillova J, Mariage-Samson R, Onno M, Huebner K, Cannizzaro LA, Boghosian-Sell L, Croce CM and Hill M: A novel transcriptional unit of the Tre oncogene widely expressed in human cancer cells. Oncogene 7: 733-741, 1992. PMID: 1565468.

4 Oliveira AM, Hsi BL, Weremowicz S, Rosenberg AE, Dal Cin P, Joseph N, Bridge JA, Perez-Atayde AR and Fletcher JA: USP6 (Tre2) fusion oncogenes in aneurysmal bone cyst. Cancer Res 64: 1920-1923, 2004. PMID: 15026324. DOI: 10.1158/0008-5472.can03-2827
5 Oliveira AM, Perez-Atayde AR, Dal Cin P, Gebhardt MC, Chen CJ, Neff JR, Demetri GD, Rosenberg AE, Bridge JA and Fletcher JA: Aneurysmal bone cyst variant translocations upregulate USP6 transcription by promoter swapping with the ZNF9, COL1A1, TRAP150 and OMD genes. Oncogene 24: 3419-3426, 2005. PMID: 15735689. DOI: 10.1038/sj.onc.1208506

6 Ye Y, Pringle LM, Lau AW, Riquelme DN, Wang H, Jiang T, Lev D, Welman A, Blobel GA, Oliveira AM and Chou MM: TRE17/USP6 oncogene translocated in aneurysmal bone cyst induces matrix metalloproteinase production via activation of NF-kB. Oncogene 29: 3619-3629, 2010. PMID: 20418905. DOI: 10.1038/onc. 2010.116

7 Madan B, Walker MP, Young R, Quick L, Orgel KA, Ryan M, Gupta P, Henrich IC, Ferrer M, Marine S, Roberts BS, Arthur WT, Berndt JD, Oliveira AM, Moon RT, Virshup DM, Chou MM and Major MB: USP6 oncogene promotes Wnt signaling by deubiquitylating Frizzleds. Proc Natl Acad Sci USA 113: E2945E2954, 2016. PMID: 27162353. DOI: 10.1073/pnas.1605691113

8 Quick L, Young R, Henrich IC, Wang X, Asmann YW, Oliveira AM and Chou MM: JAK1-STAT3 signals are essential effectors of the USP6/TRE17 oncogene in tumorigenesis. Cancer Res 76: 5337-5347, 2016. PMID: 27440725. DOI: 10.1158/00085472.CAN-15-2391

9 Li L, Yang H, He Y, Li T, Feng J, Chen W, Ao L, Shi X, Lin Y, Liu H, Zheng E, Lin Q, Bu J, Zeng Y, Zheng M, Xu Y, Liao Z, Lin J and Lin D: Ubiquitin-specific protease USP6 regulates the stability of the c-JUN protein. Mol Cell Biol 38: e00320-17, 2018. PMID: 29061731. DOI: 10.1128/MCB.00320-17

10 Nishio J: Updates on the cytogenetics and molecular cytogenetics of benign and intermediate soft tissue tumors. Oncol Lett 5: 1218, 2013. PMID: 23255885. DOI: 10.3892/ol.2012.1002

11 Oliveira AM and Chou MM: USP6-induced neoplasms: the biologic spectrum of aneurysmal bone cyst and nodular fasciitis. Hum Pathol 45: 1-11, 2014. PMID: 23769422. DOI: 10.1016/j.humpath.2013.03.005

12 Erber R and Agaimy A: Misses and near misses in diagnosing nodular fasciitis and morphologically related reactive myofibroblastic proliferations: experience of a referral center with emphasis on frequency of USP6 gene rearrangements. Virchows Arch 473: 351-360, 2018. PMID: 29623468. DOI: 10.1007/s00428-018-2350-0

13 Hiemcke-Jiwa LS, van Gorp JM, Fisher C, Creytens D, van Diest PJ and Flucke U: USP6-associated neoplasms: a rapidly expanding family of lesions. Int J Surg Pathol 28: 816-825, 2020. PMID: 32635781. DOI: 10.1177/1066896920938878

14 Oliveira AM, Wang J and Wang WL: Nodular fasciitis. In: World Health Organization Classification of Tumours of Soft Tissue and Bone. Lyon, IARC Press, pp. 49-50, 2020.

15 Sawyer JR, Sammartino G, Baker GF and Bell JM: Clonal chromosome aberrations in a case of nodular fasciitis. Cancer Genet Cytogenet 76: 154-156, 1994. PMID: 7923068. DOI: 10.1016/0165-4608(94)90469-3

16 Birdsall SH, Shipley JM, Summersgill BM, Black AJ, Jackson P, Kissin MW and Gusterson BA: Cytogenetic findings in a case of nodular fasciitis of the breast. Cancer Genet Cytogenet 81: 166-168, 1995. PMID: 7621414. DOI: 10.1016/0165-4608(94)00229-5

17 Weibolt VM, Buresh CJ, Roberts CA, Suijkerbuijk RF, Pickering DL, Neff JR and Bridge JA: Involvement of 3q21 in nodular fasciitis. Cancer Genet Cytogenet 106: 177-179, 1998. PMID: 9797787. DOI: 10.1016/s0165-4608(98)00066-1 
18 Donner LR, Silva T and Dobin SM: Clonal rearrangement of $15 \mathrm{p} 11.2,16 \mathrm{p} 11.2$, and $16 \mathrm{p} 13.3$ in a case of nodular fasciitis: additional evidence favoring nodular fasciitis as a benign neoplasm and not a reactive tumefaction. Cancer Genet Cytogenet 139: 138-140, 2002. PMID: 12550774. DOI: 10.1016/s0165-4608(02)00613-1

19 Velagaleti GVN, Tapper JK, Panova NE, Miettinen M and Gatalica Z: Cytogenetic findings in a case of nodular fasciitis of subclavicular region. Cancer Genet Cytogenet 141: 160-163, 2003. PMID: 12606136. DOI: 10.1016/s0165-4608(02)00725-2

20 Erickson-Johnson MR, Chou MM, Evers BR, Roth CW, Seys AR, Jin L, Ye Y, Lau AW, Wang X and Oliveira AM: Nodular fasciitis: a novel model of transient neoplasm induced by MYH9USP6 gene fusion. Lab Invest 91: 1427-1433, 2011. PMID: 21826056. DOI: 10.1038/labinvest.2011.118

21 Patel NR, Chrisinger JSA, Demicco EG, Sarabia SF, Reuther J, Kumar E, Oliveira AM, Billings SD, Bovée JVMG, Roy A, Lazar AJ, Lopez-Terrada DH and Wang WL: USP6 activation in nodular fasciitis by promotor-swapping gene fusions. Mod Pathol 30: 1577-1588, 2017. PMID: 27125357. DOI: 10.1038/modpathol.2017.78

22 Lam SW, Cleton-Jansen AM, Cleven AHG, Ruano D, van Wezel T, Szuhai K and Bovée JVMG: Molecular analysis of gene fusions in bone and soft tissue tumors by anchored multiplex PCR-based targeted next-generation sequencing. J Mol Diagn 20: 653-663, 2018. PMID: 30139549. DOI: 10.1016/j.jmoldx.2018.05.007

23 Lenz J, Michal M, Svajdler M, Ptakova N, Lenz D, Konecna P and Kavka M: Novel EIF5A-USP6 gene fusion in nodular fasciitis associated with unusual pathologic features: a report of a case and review of the literature. Am J Dermatopathol 42: 539-543, 2020. PMID: 31880592. DOI: 10.1097/DAD.0000000000001602

24 Wang JC, Li WS, Kao YC, Lee JC, Lee PH, Huang SC, Tsai JW, Chen CC, Chang CD, Yu SC and Huang HY: Clinicopathological and molecular characterization of USP6-rearranged soft tissue neoplasms: the evidence of genetic relatedness indicates an expanding family with variable bone-forming capacity. Histopathology, 2020. PMID: 33000481. DOI: 10.1111/his.14268

25 Qiu Y, Peng R, Chen H, Zhuang H, He X and Zhang H: Atypical nodular fasciitis with a novel PAFAH1B1-USP6 fusion in a 22month-old boy. Virchows Arch, 2020. PMID: 33161462. DOI: 10.1007/s00428-020-02961-y

26 Paulson VA, Stojanov IA, Wasman JK, Restrepo T, Cano S, Plunkitt J, Duraisamy S, Harris MH, Chute DJ, Al-Ibraheemi A and Church AJ: Recurrent and novel USP6 fusions in cranial fasciitis identified by targeted RNA sequencing. Mod Pathol 33: 775-780, 2020. PMID: 31827231. DOI: 10.1038/s41379-0190422-6

27 Lu Y, He X, Qiu Y, Chen H, Zhuang H, Yao J and Zhang H: Novel CTNNB1-USP6 fusion in intravascular fasciitis of the large vein identified by next-generation sequencing. Virchows Arch 477: 455-459, 2020. PMID: 32170450. DOI: 10.1007/s00428-020-02792-x

28 Guo R, Wang X, Chou MM, Asmann Y, Wenger DE, AlIbraheemi A, Molavi DW, Aboulafia A, Jin L, Fritchie K, Oliveira JL, Jenkins RB, Westendorf JJ, Dong J and Oliveira AM: PPP6R3-USP6 amplification: novel oncogenic mechanism in malignant nodular fasciitis. Genes Chromosomes Cancer 55: 640-649, 2016. PMID: 27113271. DOI: $10.1002 / \mathrm{gcc} .22366$

29 Teramura Y, Yamazaki Y, Tanaka M, Sugiura Y, Takazawa Y, Takeuchi K, Nakayama T, Kaneko T, Musha Y, Funauchi Y, Ae
K, Matsumoto S and Nakamura T: Case of mesenchymal tumor with the PPP6R3-USP6 fusion, possible nodular fasciitis with malignant transformation. Pathol Int 69: 706-709, 2019. PMID: 31538390. DOI: $10.1111 /$ pin.12851

30 Sciot R and Cunha IW: Fibroma of tendon sheath. In: World Health Organization Classification of Tumours of Soft Tissue and Bone. Lyon, IARC Press, pp. 67-68, 2020.

31 Chung EB and Enzinger FM: Fibroma of tendon sheath. Cancer 44: 1945-1954, 1979. PMID: 91424. DOI: 10.1002/10970142(197911)44:5<1945::aid-cncr2820440558>3.0.co;2-t

32 Nakayama S, Nishio J, Aoki M, Nabeshima K and Yamamoto T: An update on clinicopathological, imaging and genetic features of desmoplastic fibroblastoma (collagenous fibroma). In Vivo 35: 69-73, 2021. PMID: 33402451. DOI: 10.21873/invivo.12233

33 Dal Cin P, Sciot R, De Smet L and Van den Berghe H: Translocation 2;11 in a fibroma of tendon sheath. Histopathology 32: 433-435, 1998. PMID: 9639118. DOI: 10.1046/j.13652559.1998.00390.x

34 Nishio J, Iwasaki H, Nagatomo $M$ and Naito M: Fibroma of tendon sheath with $11 \mathrm{q}$ rearrangements. Anticancer Res 34: 5159-5162, 2014. PMID: 25202108.

35 Suzuki K, Yasuda T, Suzawa S, Watanabe K, Kanamori M and Kimura T: Fibroma of tendon sheath around large joints: clinical characteristics and literature review. BMC Musculoskelet Disord 18: 376, 2017. PMID: 28854920. DOI: 10.1186/s12891-017$1736-5$

36 Rubinstein A, Fitzhugh V, Ahmed I and Vosbikian M: A case of 14-year-old male with fibroma of tendon sheath of the hand with novel chromosomal translocation 4;10. Case Rep Orthop 2019: 3514013, 2019. PMID: 31637074. DOI: 10.1155/2019/3514013

37 Carter JM, Wang X, Dong J, Westendorf J, Chou MM and Oliveira AM: USP6 genetic rearrangements in cellular fibroma of tendon sheath. Mod Pathol 29: 865-869, 2016. PMID: 27125357. DOI: 10.1038 /modpathol.2016.83

38 Mantilla JG, Gross JM, Liu YJ, Hoch BL and Ricciotti RW: Characterization of novel USP6 gene rearrangements in a subset of so-called cellular fibroma of tendon sheath. Mod Pathol 34: 1319, 2021. PMID: 32661296. DOI: 10.1038/s41379-020-0621-1

39 Oliveira AM and Rosenberg AE: Myositis ossificans and fibroosseous pseudotumour of digits. In: World Health Organization Classification of Tumours of Soft Tissue and Bone. Lyon, IARC Press, pp. 53-54, 2020.

40 de Silva MV and Reid R: Myositis ossificans and fibroosseous pseudotumor of digits: a clinicopathological review of 64 cases with emphasis on diagnostic pitfalls. Int J Surg Pathol 11: 187-195, 2003. PMID: 12894350. DOI: 10.1177/106689690301100305

41 Sukov WR, Franco MF, Erickson-Johnson M, Chou MM, Unni $\mathrm{KK}$, Wenger DE, Wang X and Oliveira AM: Frequency of USP6 rearrangements in myositis ossificans, brown tumor, and cherubism: molecular cytogenetic evidence that a subset of "myositis ossificans-like lesions" are the early phases in the formation of soft-tissue aneurysmal bone cyst. Skeletal Radiol 37: 321-327, 2008. PMID: 18265974. DOI: 10.1007/s00256007-0442-z

42 Bekers EM, Eijkelenboom A, Grünberg K, Roverts RC, de Rooy JWJ, van der Geest ICM, van Gorp JM, Creytens D and Flucke U: Myositis ossificans - another condition with USP6 rearrangement, providing evidence of a relationship with nodular fasciitis and aneurysmal bone cyst. Ann Diagn Pathol 34: 56-59, 2018. PMID: 29661729. DOI: 10.1016/j.anndiagpath.2018.01.006 
43 Flucke U, Bekers EM, Creytens D and van Gorp JM: COL1A1 is a fusion partner of USP6 in myositis ossificans - FISH analysis of six cases. Ann Diagn Pathol 36: 61-62, 2018. PMID: 29980413. DOI: 10.1016/j.anndiagpath.2018.06.009

44 Švajdler M, Michal M, Martínek P, Ptáková N, Kinkor Z, Szépe P, Švajdler P, Mezencev R and Michal M: Fibro-osseous pseudotumor of digits and myositis ossificans show consistent COL1A1-USP6 rearrangement: a clinicopathological and genetic study of 27 cases. Hum Pathol 88: 39-47, 2019. PMID: 30946936. DOI: 10.1016/j.humpath.2019.02.009

45 Song W, Suurmeijer AJH, Bollen SM, Cleton-Jansen AM, Bovée JVMG and Kroon HM: Soft tissue aneurysmal bone cyst: six new cases with imaging details, molecular pathology, and review of the literature. Skeletal Radiol 48: 1059-1067, 2019. PMID: 30603771. DOI: 10.1007/s00256-018-3135-x

46 Zhang L, Hwang S, Benayed R, Zhu GG, Mullaney KA, Rios KM, Sukhadia PY, Agaram N, Zhang Y, Bridge JA, Healey JH, Athanasian EA and Hameed M: Myositis ossificans-like soft tissue aneurysmal bone cyst: a clinical, radiological, and pathological study of seven cases with COL1A1-USP6 fusion and a novel ANGPTL2-USP6 fusion. Mod Pathol 33: 1492-1504, 2020. PMID: 32157177. DOI: 10.1038/s41379-020-0513-4

47 Nishio J, Iwasaki H, Soejima O, Naito M and Kikuchi M: Rapidly growing fibro-osseous pseudotumor of the digits mimicking extraskeletal osteosarcoma. J Orthop Sci 7: 410-413, 2002. PMID: 12077672. DOI: 10.1007/s007760200070

48 Moosavi CA, Al-Nahar LA, Murphey MD and Fanburg-Smith JC: Fibroosseous pseudotumor of the digit: a clinicopathologic study of 43 new cases. Ann Diagn Pathol 12: 21-28, 2008. PMID: 18164411. DOI: 10.1016/j.anndiagpath.2007.02.001
49 Chaudhry IH, Kazakov DV, Michal M, Mentzel T, Luzar B and Calonje E: Fibro-osseous pseudotumor of the digit: a clinicopathological study of 17 cases. J Cutan Pathol 37: 323-329, 2010. PMID: 19678826. DOI: 10.1111/j.1600-0560.2009.01385.x

50 Flucke U, Shepard SJ, Bekers EM, Tirabosco R, van Diest PJ, Creytens D and van Gorp JM: Fibro-osseous pseudotumor of digits - expanding the spectrum of clonal transient neoplasms harboring USP6 rearrangement. Ann Diagn Pathol 35: 53-55, 2018. PMID: 29787930. DOI: 10.1016/j.anndiagpath.2018.05.003

51 Dermawan JK, Cheng YW, Tu ZJ, Meyer A, Habeeb O, Zou Y, Goldblum JR, Billings SD, Kilpatrick SE, Reith JD, Shurtleff SA, Farkas DH, Rubin BP and Azzato EM: Diagnostic utility of a custom 34-gene anchored multiplex PCR-based nextgeneration sequencing fusion panel for the diagnosis of bone and soft tissue neoplasms with identification of novel USP6 fusion partners in aneurysmal bone cysts. Arch Pathol Lab Med, 2020. PMID: 33147323. DOI: 10.5858/arpa.2020-0336-OA

52 Konishi E, Kusuzaki K, Murata H, Tsuchihashi Y, Beabout JW and Unni KK: Extraskeletal osteosarcoma arising myositis ossificans. Skeletal Radiol 30: 39-43, 2001. PMID: 11289633. DOI: $10.1007 / \mathrm{s} 002560000298$
Received January 5, 2021

Revised January 17, 2021

Accepted January 18, 2021 